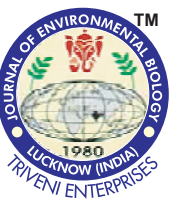

DOI : http://doi.org/10.22438/jeb/39/3/MRN-552

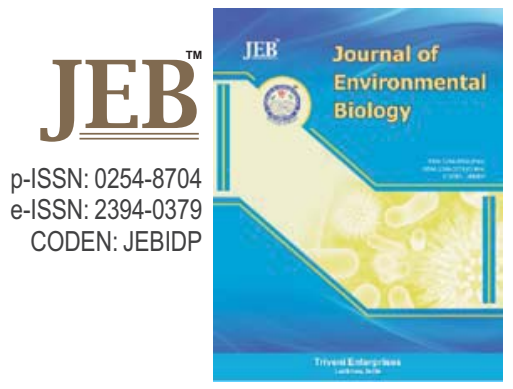

\title{
Assessing phytotoxic limits of nickel in intensively cultivated alluvial soils
}

Authors Info

M. Barman and S.P. Datta*
Division of Soil Science and
Agricultural Chemistry,
ICAR-Indian Agricultural Research
Institute, New Delhi-110 012, India

*Corresponding Author Email : spdatta.manish@gmail.com

\section{Key words \\ Alluvial soil \\ Critical limit \\ Nickel \\ Phytotoxicity \\ Soybean}

\section{Publication Info}

Paper received : 03.12 .2016

Revised received : 12.05 .2017

Re-revised received : 22.07 .2017

Accepted : 28.09.2017

\begin{abstract}
Aim : Studies on nickel pollution in soil have been mostly confined to its determination in soils receiving sewage sludge and industrial effluents and no systematic effort has been made to work out its phytotoxic limits in soil and plant. Hence, an attempt was made to establish the phytotoxic limit of Ni in alluvial soils and soybean plant.
\end{abstract}

Methodology : A greenhouse experiment was carried out with fifteen bulk surface $(0-15 \mathrm{~cm})$ soil samples. These samples were collected from cultivated fields receiving irrigation through fresh water, sewage and industrial effluents. Nickel was applied @ 0, 5, 50 and $100 \mathrm{mg} \mathrm{kg}^{-1}$ as NiSO${ }_{4} \cdot 6 \mathrm{H}_{2} \mathrm{O}$. Soybean plants grew up to flowering stage. Post harvest soil samples were extracted with DTPA and plant samples were digested with di-acid. Nickel content in the extract was measured using atomic absorption spectrophotometer.

Results : On an average, dry matter yield of soybean was reduced by $1.56,17.9$ and $29.2 \%$ at 5,50 and $100 \mathrm{mg} \mathrm{kg}^{-1}$ of applied Ni, respectively, over control due to phyotoxicity.

Interpretation : Phytotoxic limits of DTPA extractable Ni in soil and total Ni content in plant were computed as 3.24 and $12.0 \mathrm{mg} \mathrm{kg}^{-1}$, respectively.

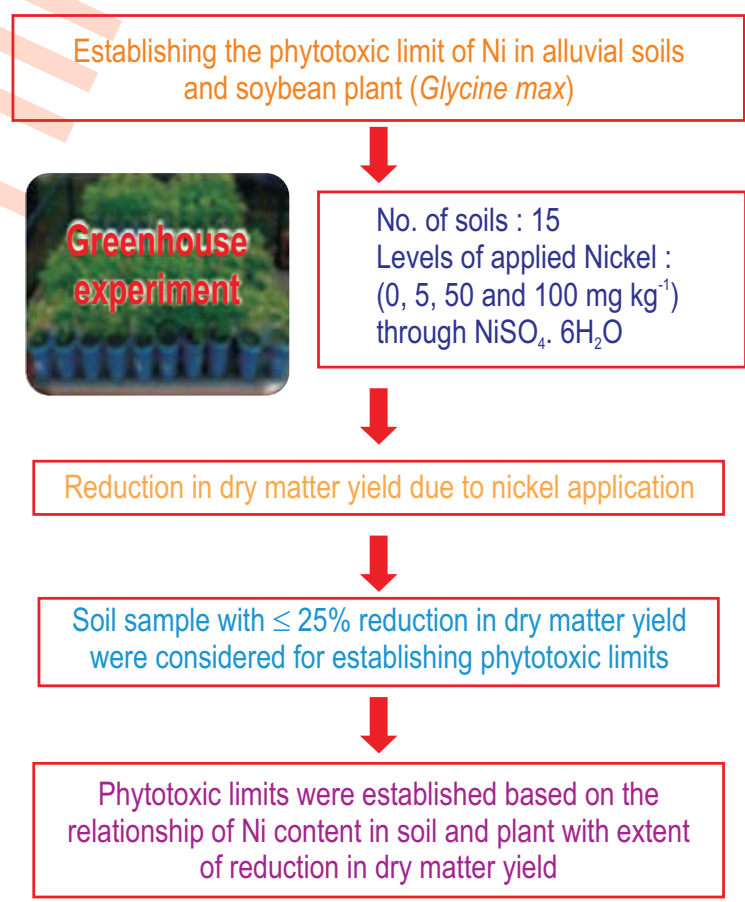




\section{Introduction}

Nickel is an essential nutrient for plants, animals and microorganisms (Brown et al., 1987; Cempel and Nikel, 2006). Positive effects of this element at low concentration have been reported in several crops, but plant growth is adversely affected with increase in its concentration (Cempel and Nikel, 2006; Seregin and Kozhevnikova, 2006; Gautam and Pandey, 2008). Excessive Ni can alter plant metabolism leading to inhibition of germination and growth (Khan and Khan, 2010). Stunted growth, chlorosis and necrosis of leaves are visible symptoms associated with toxicity (Seregin and Kozhevnikova, 2006). The elevated level of $\mathrm{Ni}$ in agricultural fields receiving sewage sludge and industrially polluted river water is a matter of concern (Indra and Sivaji, 2006). Food chain contamination with $\mathrm{Ni}$ can cause detrimental effects on animals and human (Cempel and Nikel, 2006). In 2008, Ni received the shameful name of the "Allergen of the year" (Duda-Chodak and Blaszczyk, 2008). Excessive Ni exposure may cause oxidative stress in plants (Mittler, 2002). Elevated level of $\mathrm{Ni}$ in soil and plants induces $\mathrm{Zn}$ or Fe deficiency leading to chlorosis (Anderson et al., 1973).

Seregin and Kozhevnikova (2006) presented an excellent review on the role of $\mathrm{Ni}$, including toxic effects on plants. The various aspects related to physiological role of $\mathrm{Ni}$ were discussed in detail. Reduction in biomass yield of different crops due to Ni toxicity has been reported (Weng et al., 2003; Kukier and Chaney, 2004; Fargasova and Molnarova, 2010; Ishtiaq and Mahmood, 2011). In none of these studies, toxicity limits of extractable $\mathrm{Ni}$ in soil was established, which otherwise would have much more practical implication and utility in delineating soil having toxic level of Ni. In India, Pande et al. (2012) established phytotoxic limits of DTPA extractable Ni in soil (Mollisol) and french bean as 3.5 and $18.0 \mathrm{mg} \mathrm{kg}^{-1}$, respectively, using only one bulk soil. They also reported that these threshold limits varied with applied farmyard manure (FYM). Such information is not available for alluvial soils of Indo-Gangetic plains, which have much lower level of organic matter compared to Mollisol. In the present investigation, an attempt was made to establish phytotoxic limits of $\mathrm{Ni}$ in soils and plants using soybean as a test crop. Since Ni plays an important role in nitrogen metabolism particularly in legumes being a structural component of urease and hydrogenase, soybean was selected as test crop.

\section{Materials and Methods}

Collection and analyses of soils : Fifteen surface $(0$ to $15 \mathrm{~cm})$ soil samples were collected from agricultural fields in and around Delhi. Four soil samples (Soil 1, 2, 3 and 4) were collected from intensively cultivated IARI farm of about seven decade old. Five soil samples (Soil 5, 6, 7, 8 and 9) were collected from agricultural lands of Keshopur, Delhi, receiving irrigation through sewage water for three decades. Four soil samples (Soil 10, 12, 13 and 14) belonging to agricultural lands of Madanpur, Delhi which have been receiving irrigation either through tubewell water or the river Yamuna. One soil (Soil 11) collected from agricultural land of Madanpur, Delhi which has been receiving sewage irrigation for last five decades. One sample (Soil 15) was taken from agricultural fields close to ATLAS cycle factory, Sonipat, Haryana, which has a history of irrigation through industrial effluents for fifteen years. The soil samples were processed through drying, grinding and sieving $(2 \mathrm{~mm})$. Initial soil properties were determined using standard methods (Page, 1982). Mechanical composition, organic carbon and cation exchange capacity (CEC) of soil was measured by hydrometer, wet oxidation and ammonium acetate methods, respectively. Soil pH was measured in 1:2 soil: water suspension. Citrate bicarbonate dithionite was used to extract free $\mathrm{Fe}_{2} \mathrm{O}_{3}$ and $\mathrm{Al}_{2} \mathrm{O}_{3}$. $\mathrm{Fe}$ and $\mathrm{Al}$ content in the extract were measured by atomic absorption spectrophotometer and aluminon method, respectively (Page, 1982).

Greenhouse pot experiment : Four kg of soil was taken in pots and a uniform basal dose ( $150 \%$ of recommended dose of NPK) of $20,17.5$ and $22.5 \mathrm{mg} \mathrm{kg}^{-1}$ of N, $\mathrm{P}$ and $\mathrm{K}$ was added in solution form using urea, di-ammonium phosphate and muriate of potash, respectively. Following the incorporation of these nutrients into soil, Ni was applied @ 0, 5, 50 and $100 \mathrm{mg} \mathrm{kg}^{-1}$ as sulphate salt of $\mathrm{Ni}\left(\mathrm{Ni}_{2} \mathrm{SO}_{4} \cdot 6 \mathrm{H}_{2} \mathrm{O}\right)$. The pots were irrigated to field capacity with deionised water and incubated for one week. Healthy seeds of soybean were sown. A uniform population of six plants per pot was maintained and harvested at flowering stage ( 55 days of sowing).

Soil extraction : At harvest of soybean, soil was removed, mixed, dried, ground and sieved ( $2 \mathrm{~mm}$ sieve). These soil samples along with initial soil samples were extracted for Ni using 0.005 M DTPA (Lindsay and Norvell, 1978). Nickel content in DTPA extract was measured using flame and graphite atomic absorption spectrophotometer.

Plant analysis : Plants after harvesting were washed with deionised water and dried in hot air oven at $60-70^{\circ} \mathrm{C}$. Dry matter yield was noted. Ground plant samples were digested with di-acid mixture $\left(\mathrm{HNO}_{3}: \mathrm{HClO}_{4}::\right.$ 10:4) and $\mathrm{Ni}$ content in the digest was estimated by flame and graphite AAS.

Phytotoxic limits of nickel in soil and plant : Critical limit of Ni toxicity in soil and plant were computed using statistical method of Cate and Nelson (1971). In this procedure, relative yield data were divided into two classes through iteration based upon maximisation of the class sum of square (CSS). The class sum of squares reflect the weighted sum of squares of the differences between the relative yield means for two classes and the grand mean. Using this procedure, quantitatively best division from the point of view of maximising mean differences between not affected and adversely affected due to Ni toxicity can be worked out. While doing so, relative yield was calculated as (yield at applied Ni/yield at control) X 100, and soil samples with $\leq 25 \%$ 
reduction in dry matter yield was considered for calculation of relative yield. Soil samples responded at $5 \mathrm{mg} \mathrm{kg}^{-1}$ of applied $\mathrm{Ni}$ was also not included, because these soil samples were deficient of available Ni. Relative yield of soybean for such samples would be more than $100 \%$ leading to establish pseudo toxic limit of $\mathrm{Ni}$.

Statistical analysis : Impact of applied Ni on Ni content in soil and plant as well as dry matter yield of soybean was worked out adopting a completely randomized design.

\section{Results and Discussion}

Physical and chemical properties of initial soil : The soil samples were selected for the present investigation ensuring wide variation in properties (Table 1). Soil pH was in neutral to alkaline range ( $\mathrm{pH} 6.87$ to 8.32). All the soils were non-saline as EC ranged between 0.23 and $1.21 \mathrm{dS} \mathrm{m}^{-1}$, except soil 6 and 9 which showed relatively higher values of EC. Soil organic carbon ranged from 0.04 to $1.17 \%$. The CEC of soils ranged from 4.6 to $19.4 \mathrm{cmol}\left(\mathrm{p}^{+}\right) \mathrm{kg}^{-1}$. There was a wide variation in both clay as well as organic carbon content in soils, which was also reflected well in CEC. Free $\mathrm{Fe}_{2} \mathrm{O}_{3}$ and $\mathrm{Al}_{2} \mathrm{O}_{3}$ in soils ranged from 0.06 to $1.67 \%$ and 0.03 to $0.99 \%$, respectively. DTPA extractable Ni in experimental soils ranged from 0.06 to $9.91 \mathrm{mg} \mathrm{kg}^{-1}$. Important soil properties showed ample variation, which is a prerequisite for establishing phytotoxic limits.

Extractable nickel in post-harvest soils : The DTPA extractable $\mathrm{Ni}$ in post-harvest control soil (without applied $\mathrm{Ni}$ ) varied from 0.06 to $9.33 \mathrm{mg} \mathrm{kg}^{-1}$ (Fig. 1). There was a significant increase in DTPA extractable Ni content in soil due to application of $\mathrm{Ni}$. The mean value of DTPA extractable Ni in soil increased from $1.23 \mathrm{mg} \mathrm{kg}^{-1}$ (control) to $2.13,16.3$ and $28.0 \mathrm{mg} \mathrm{kg}^{-1}$ at 5,50 and $100 \mathrm{mg} \mathrm{kg}^{-1}$ of applied $\mathrm{Ni}$, respectively. Extractable $\mathrm{Ni}$ in soils showed a wide variation even at the same level of applied $\mathrm{Ni}$, which emphasizes the importance of soil properties in maintaining the availability of applied Ni. Variation in initial available Ni content may be attributed to different sources of irrigation water used for growing crops in these soils and wide variation in inherent soil properties. Huge accumulation of $\mathrm{Ni}$ in industrial effluent irrigated soils has also been reported earlier by Barman et al. (2014).

Symptoms of nickel toxicity : By and large, toxicity symptoms were observed in soybean plants receiving 50 and $100 \mathrm{mg} \mathrm{Ni} \mathrm{kg}^{-1}$ through $\mathrm{NiSO}_{4}$. Toxicity symptoms in soybean plants were observed in case of soil no.15 even in control. However, the extent of toxicity varied among the different soils. After emergence, no symptoms of Ni toxicity were present in soybean, except that grown on soil 15, where yellowing of young leaves occurred. Toxicity symptoms appeared in plants at 50 and $100 \mathrm{mg}$ $\mathrm{kg}^{-1}$ of applied Ni for all soils after 20 days of sowing. Chlorosis including brown spots on primary leaves of soybean appeared initially. Later on, chlorosis was converted into reddish brown necrotic spots. In some cases curling of leaves also appeared. Such types of toxicity symptom of $\mathrm{Ni}$ in soybean were also described by some other researchers (Kukier and Chaney, 2004; Amari et al., 2014; Nie et al., 2015).

Biomass yield and nickel content of soybean : Soil Ni levels significantly influenced the dry matter yield of soybean (Fig. 2). The main observable effect of applied Ni on soybean was progressive decrease in dry matter yield with increasing Ni levels in comparison

Table 1: Physical and chemical properties of experimental soils

\begin{tabular}{|c|c|c|c|c|c|c|c|c|c|c|c|c|}
\hline \multirow{2}{*}{$\begin{array}{l}\text { Soil } \\
\text { No. }\end{array}$} & \multirow[t]{2}{*}{ Site } & \multicolumn{3}{|c|}{ Soil separates (\%) } & \multirow{2}{*}{\multicolumn{2}{|c|}{$\begin{array}{l}\text { Textural pH } \\
\text { class }\end{array}$}} & \multirow{2}{*}{$\begin{array}{l}E C \\
\left(\mathrm{dS} \mathrm{m} \mathrm{m}^{-1}\right)\end{array}$} & \multirow{2}{*}{$\begin{array}{l}\text { CEC }\left(\mathrm{cmol}^{-1}\right. \\
\left.(\mathrm{p}+) \mathrm{kg}^{-1}\right)\end{array}$} & \multirow{2}{*}{$\begin{array}{l}\text { Organic } \\
\text { carbon } \\
(\%)\end{array}$} & \multirow{2}{*}{$\begin{array}{l}\text { Free } \\
\mathrm{Fe}_{2} \mathrm{O}_{3}(\%)\end{array}$} & \multirow{2}{*}{$\begin{array}{l}\text { Free } \\
\mathrm{Al}_{2} \mathrm{O}_{3}(\%)\end{array}$} & \multirow{2}{*}{$\begin{array}{l}\text { DTPA } \\
\text { extractable } \\
\mathrm{Ni}\left(\mathrm{mg} \mathrm{kg}^{-1}\right)\end{array}$} \\
\hline & & Clay & Silt & Sand & & & & & & & & \\
\hline 1 & $A$ & 19.9 & 16 & 64.1 & SL & 8.14 & 0.24 & 14.2 & 0.44 & 0.25 & 0.06 & 0.20 \\
\hline 2 & & 38.6 & 12.0 & 49.3 & SCL & 8.09 & 0.74 & 19.4 & 0.65 & 0.35 & 0.06 & 0.29 \\
\hline 3 & & 22.6 & 10.0 & 67.3 & SCL & 7.90 & 0.25 & 12.6 & 0.44 & 0.26 & 0.07 & 0.38 \\
\hline 4 & & 24.8 & 22.0 & 53.1 & SCL & 8.15 & 0.23 & 8.4 & 0.29 & 0.41 & 0.05 & 0.37 \\
\hline 5 & $B$ & 18.6 & 69.3 & 12.0 & SIL & 7.65 & 0.80 & 20.4 & 0.92 & 0.17 & 0.04 & 1.58 \\
\hline 6 & & 10.8 & 16.0 & 73.1 & SL & 7.94 & 2.59 & 12.0 & 0.57 & 0.13 & 0.03 & 1.39 \\
\hline 7 & & 10.6 & 20.0 & 69.3 & SL & 6.89 & 1.11 & 14.4 & 0.69 & 0.21 & 0.03 & 1.59 \\
\hline 8 & & 16.6 & 4.0 & 79.3 & SL & 6.87 & 0.32 & 14.8 & 0.63 & 0.18 & 0.04 & 2.98 \\
\hline 9 & & 18.6 & 12.0 & 69.3 & SL & 7.81 & 3.90 & 14.8 & 0.91 & 0.18 & 0.06 & 1.40 \\
\hline 10 & $C$ & 4.88 & 73.1 & 22.0 & SIL & 7.90 & 1.06 & 9.60 & 0.18 & 0.15 & 0.03 & 0.12 \\
\hline 11 & & 16.6 & 6.0 & 77.3 & SL & 7.30 & 0.47 & 15.2 & 1.17 & 0.11 & 0.04 & 0.31 \\
\hline 12 & & 2.88 & 4.0 & 93.1 & $S$ & 8.32 & 0.25 & 4.60 & 0.04 & 0.06 & 0.06 & 0.06 \\
\hline 13 & & 8.88 & 32.0 & 59.1 & SL & 7.97 & 0.85 & 11.8 & 0.20 & 0.16 & 0.99 & 0.12 \\
\hline 14 & & 4.88 & 50.0 & 45.1 & SIL & 7.95 & 1.21 & 10.4 & 0.26 & 0.21 & 0.09 & 0.15 \\
\hline 15 & $D$ & 18.8 & 30.0 & 51.1 & $\mathrm{~L}$ & 8.05 & 0.49 & 12.4 & 0.64 & 1.67 & 0.13 & 9.91 \\
\hline
\end{tabular}

LocatonA: IARI farm, B: Keshopur, Delhi C: Madanpur, Delhi, D: Sonepat, Haryana; Textural class SL: Sandy loam, SCL: Sandy clay loam,SIL: Silt loam, S: Sand, L: Loam 


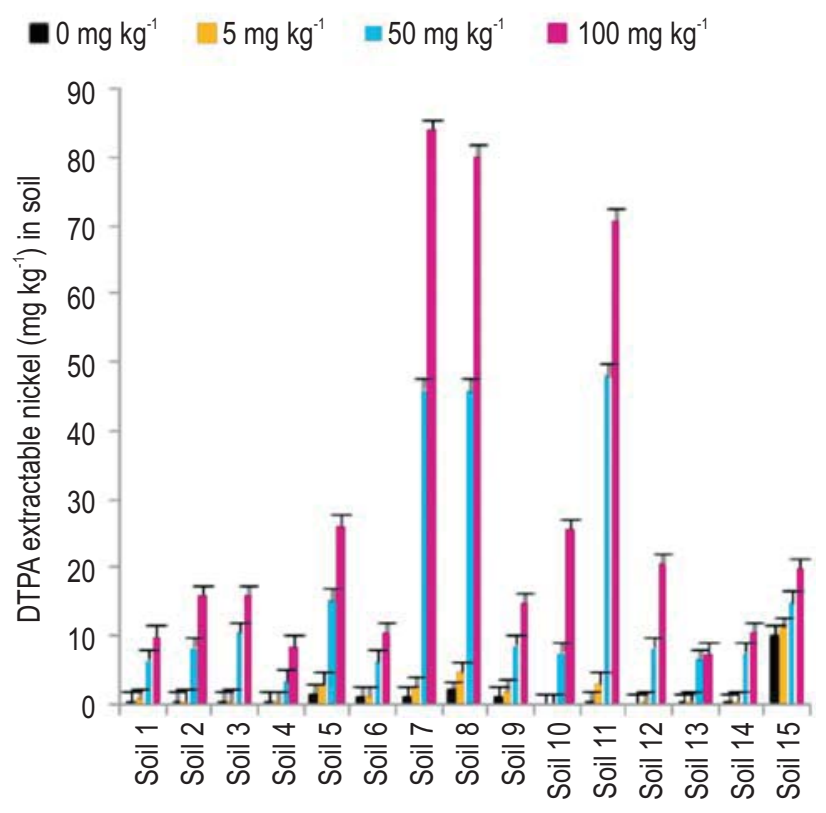

Fig. 1 : Effect of nickel application on DTPA extractable nickel $\left(\mathrm{mg} \mathrm{kg}^{-1}\right)$ in soil after harvest of soybean

with those of the controls, which was likely due to the deleterious effect of Ni on numerous physiological processes (Krupa et al., 1987). On an average, dry matter yield declined to the extent of 1.56, 17.9 and $29.2 \%$ at 5,50 and $100 \mathrm{mg} \mathrm{kg}^{-1}$ of $\mathrm{Ni}$ treatment respectively, compared to control. Perusal of the result revealed that in most of the soils, considerable reduction in biomass yield of soybean was observed, particularly at 50 and $100 \mathrm{mg} \mathrm{kg}^{-1}$ of applied $\mathrm{Ni}$. It is reported that excessive intake of $\mathrm{Ni}$ by plants usually damage the roots, which subsequently results in poor absorption and translocation of all major nutrient elements and water (Syam, N. et al., 2016). This might have been responsible for reduction in biomass yield. There was also a substantial variation in the mean biomass yield of soybean grown on different soils. Such variation in biomass yield is a reflection of wide variation in the physico-chemical properties of soil. The soil $\mathrm{Ni}$ application positively influenced the concentration of Ni in soybean (Fig. 3). On an average, Ni content of soybean increased from 1.29 (control) to $3.90,15.6$ and $24.9 \mathrm{mg} \mathrm{kg}^{-1}$ at 5,50 and $100 \mathrm{mg} \mathrm{kg}^{-1}$ of applied $\mathrm{Ni}$ in soil, respectively. Despite the fact that $\mathrm{Ni}$ is a plant essential element, excessive accumulation of this nutrient in plant may cause toxicity and can modify different physiological and biochemical processes (Seregin and Kozhevnikova, 2006). Nickel toxicity reduces cell membrane permeability due to elevated extracellular peroxidase activity (Pandolfini et al., 1992). Excessive accumulation of Ni may interfere with other essential nutrients by competition for uptake, and thereby disturbs mineral nutrition of plants (El-Enany et al., 2000). Several researchers observed that biomass yields of maize, wheat, ryegrass, cabbage, white clover, bean and sunflower were significantly reduced in response to higher rates of Ni addition (El-Enany et al., 2000; Sabir et al., 2011).

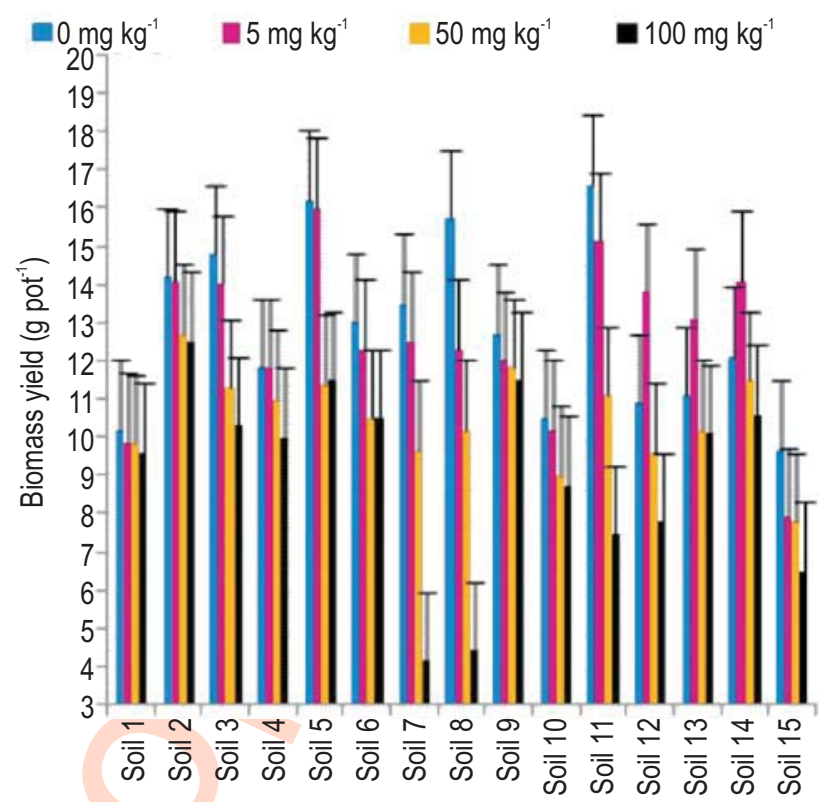

Fig. 2 : Effect of nickel application on the biomass yield $\left(\mathrm{g} \mathrm{pot}^{-1}\right)$ of soybean at flowering stage

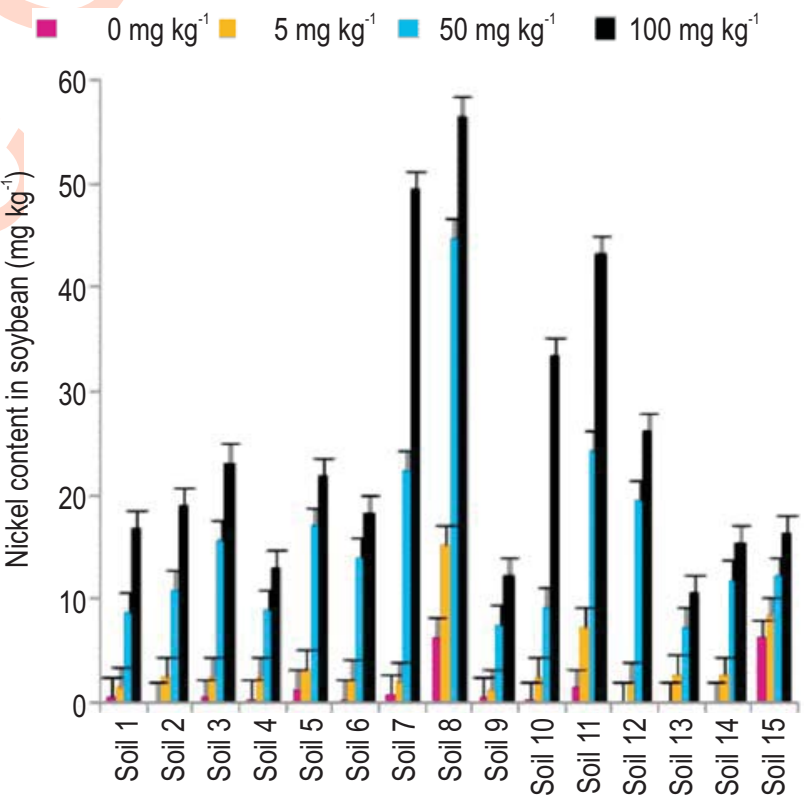

Fig. 3 : Effect of nickel application on nickel content $\left(\mathrm{mg} \mathrm{kg}^{-1}\right)$ in soybean

Toxic limit of nickel in soil and plant : Relative yield of soybean ranged from 28.2 to $126 \%$ across experimental soils (Table 2). Three soils (Soil 12, 13 and 14) responded positively to the applied Ni @ $5 \mathrm{mg} \mathrm{kg}^{-1}$ soil. In eleven cases, particularly at 50 and $100 \mathrm{mg} \mathrm{kg}^{-1}$ of applied $\mathrm{Ni}$, relative yield ranged from 28.2 to 71.6 $\%$. These data were not included while calculating the phytotoxic limit of $\mathrm{Ni}$. By and large, these low values of relative yield correspond to exceptionally high $\mathrm{Ni}$ content in soil and plant. It 
Table 2 : Relative yield (\%) of soybean at different levels of $\mathrm{Ni}$ application in soil

\begin{tabular}{llll}
\hline Soil & \multicolumn{3}{c}{ Levels of applied Ni $\left(\mathrm{mg} \mathrm{kg}^{-1}\right)$} \\
\cline { 2 - 4 } & $\mathbf{5}$ & $\mathbf{5 0}$ & 100 \\
\hline 1 & 96.8 & 96.6 & 94.1 \\
2 & 99.3 & 89.4 & 88.0 \\
3 & 94.6 & 76.4 & 69.6 \\
4 & 100 & 93.2 & 84.7 \\
5 & 98.8 & 70.4 & 71.0 \\
6 & 94.6 & 80.8 & 80.8 \\
7 & 92.6 & 71.6 & 30.7 \\
8 & 78.3 & 65.0 & 28.2 \\
9 & 94.5 & 92.9 & 90.6 \\
10 & 97.1 & 85.7 & 83.4 \\
11 & 91.0 & 66.9 & 45.1 \\
12 & 126 & 88.1 & 71.6 \\
13 & 118 & 91.9 & 91.0 \\
14 & 116 & 95.0 & 87.6 \\
15 & 82.1 & 80.5 & 67.2 \\
\hline
\end{tabular}

was thought proper that there was no point of fixing toxic limits with such exceptionally high values of $\mathrm{Ni}$ content in soil and plant. Because such toxicity limit cannot be used as a guide value to protect plant from the adverse effect of Ni toxicity. The order of decrease in relative yield in different soils was as follows: soil 8> soil $7>$ soil $11>$ soil $15>$ soil $5>$ soil $3>$ soil $6>$ soil $10>$ soil $2>$ soil 9> soil $4>$ soil $12>$ soil $1>$ soil $14>$ soil 13 . Relatively higher decrease were found in soils collected from sewage irrigated areas of Keshopur and Madanpur as well as in the industrial effluent irrigated soil of Sonepat, Haryana.

DTPA extractable $\mathrm{Ni}$ in soils in ascending order with corresponding relative yield with respect of toxicity are presented in Table 3. DTPA extractable Ni in soils ranged from 0.17 to 25.5 $\mathrm{mg} \mathrm{kg}^{-1}$ indicating a wide variation, which is a pre-requisite for working out the phytotoxic limit. Plant Ni content, as arranged in ascending order (Table 4), varied from 1.21 to $33.2 \mathrm{mg} \mathrm{kg}^{-1}$, which is a good reflection of variation recorded in DTPA extractable $\mathrm{Ni}$ in soils. Maximum value of prediction coefficient $\left(r^{2}=0.46\right)$ was

Table 3 : Analysis of variance method for computation of critical limit of toxicity of DTPAextractable nickel in soil $\left(\mathrm{mg} \mathrm{kg}^{-1}\right)$ for soybean

\begin{tabular}{|c|c|c|c|c|}
\hline S. No. & DTPA extractable Ni ( $\left.\mathrm{mg} \mathrm{kg}^{-1}\right)$ & Relative yield (\%) of soybean & Class sum of square & $r^{2}$ \\
\hline 1 & 0.17 & 96.9 & & \\
\hline 2 & 0.36 & 99.8 & 145 & 0.11 \\
\hline 3 & 0.57 & 99.4 & 246 & 0.19 \\
\hline 4 & 0.65 & 94.5 & 262 & 0.20 \\
\hline 5 & 0.86 & 97.2 & 332 & 0.25 \\
\hline 6 & 1.24 & 94.4 & 358 & 0.27 \\
\hline 7 & 2.03 & 94.5 & 391 & 0.30 \\
\hline 8 & 2.67 & 92.8 & 400 & 0.31 \\
\hline 9 & 3.12 & 99.2 & 524 & 0.40 \\
\hline 10 & 3.16 & 90.8 & 506 & 0.39 \\
\hline 11 & 3.44 & 92.7 & 527 & 0.40 \\
\hline 12 & 4.66 & 78.4 & 332 & 0.25 \\
\hline 13 & 6.39 & 80.5 & 210 & 0.16 \\
\hline 14 & 6.44 & 97 & 28 & 0.22 \\
\hline 15 & 6.66 & 92.5 & 312 & 0.24 \\
\hline 16 & 7.43 & 91.8 & 334 & 0.26 \\
\hline 17 & 7.63 & 85.6 & 280 & 0.21 \\
\hline 18 & 7.67 & 95.3 & 352 & 0.27 \\
\hline 19 & 8.23 & 88.1 & 334 & 0.26 \\
\hline 20 & 8.24 & 89.2 & 334 & 0.26 \\
\hline 21 & 8.57 & 84.8 & 278 & 0.21 \\
\hline 22 & 8.62 & 92.8 & 333 & 0.25 \\
\hline 23 & 10.0 & 94.6 & 432 & 0.33 \\
\hline 24 & 10.5 & 80.7 & 314 & 0.24 \\
\hline 25 & 10.6 & 76.6 & 159 & 0.12 \\
\hline 26 & 10.6 & 87.9 & 155 & 0.12 \\
\hline 27 & 11.2 & 82.1 & 88.6 & 0.07 \\
\hline 28 & 14.7 & 90.8 & 123 & 0.09 \\
\hline 29 & 15.0 & 80.4 & 39.4 & 0.03 \\
\hline 30 & 15.9 & 88.2 & & \\
\hline 31 & 25.5 & 83.4 & & \\
\hline
\end{tabular}

Crtical limit $=(3.12+3.16+3.44) / 3=3.24$ 
Table 4 : Analysis of variance method for computation of critical limit of toxicity of nickel content $\left(\mathrm{mg} \mathrm{kg}^{-1}\right)$ in soybean

\begin{tabular}{|c|c|c|c|c|}
\hline S. No. & Ni content in soybean $\left(\mathrm{mg} \mathrm{kg}^{-1}\right)$ & Relative yield (\%) of soybean & Class sum of square & $r^{2}$ \\
\hline 1 & 1.21 & 94.5 & & \\
\hline 2 & 1.45 & 97.2 & 70.8 & 0.05 \\
\hline 3 & 2.02 & 92.8 & 74.6 & 0.06 \\
\hline 4 & 2.21 & 94.4 & 98.5 & 0.08 \\
\hline 5 & 2.44 & 99.8 & 190 & 0.15 \\
\hline 6 & 2.48 & 96.9 & 253 & 0.19 \\
\hline 7 & 2.56 & 99.4 & 362 & 0.28 \\
\hline 8 & 2.59 & 94.5 & 400 & 0.31 \\
\hline 9 & 3.22 & 99.2 & 524 & 0.40 \\
\hline 10 & 7.21 & 92.5 & 536 & 0.41 \\
\hline 11 & 7.33 & 90.8 & 523 & 0.40 \\
\hline 12 & 7.45 & 92.8 & 551 & 0.42 \\
\hline 13 & 8.36 & 82.1 & 410 & 0.31 \\
\hline 14 & 8.75 & 97.0 & 510 & 0.39 \\
\hline 15 & 9.06 & 92.7 & 549 & 0.42 \\
\hline 16 & 9.27 & 85.6 & 475 & 0.36 \\
\hline 17 & 10.4 & 91.8 & 507 & 0.39 \\
\hline 18 & 10.9 & 89.2 & 501 & 0.38 \\
\hline 19 & 11.8 & 95.3 & 605 & 0.46 \\
\hline 20 & 12.2 & 80.4 & 458 & 0.35 \\
\hline 21 & 12.2 & 90.8 & 492 & 0.38 \\
\hline 22 & 12.8 & 84.8 & 430 & 0.33 \\
\hline 23 & 14.1 & 80.5 & 309 & 0.24 \\
\hline 24 & 15.2 & 78.4 & 179 & 0.14 \\
\hline 25 & 15.3 & 87.9 & 173 & 0.13 \\
\hline 26 & 15.6 & 76.6 & 57.1 & 0.04 \\
\hline 27 & 16.7 & 94.6 & 114 & 0.09 \\
\hline 28 & 18.2 & 80.7 & 41.4 & 0.03 \\
\hline 29 & 18.9 & 88.2 & 40.3 & 0.03 \\
\hline 30 & 19.5 & 88.1 & & \\
\hline 31 & 33.2 & 83.4 & & \\
\hline
\end{tabular}

Critical limit $=(11.8+12.2) / 2=12.0$

obtained in S. No. 19. Hence, mean value of plant Ni content in the class in question (S. No. 19) and succeeding class was worked out as phytotoxic limit of $\mathrm{Ni}$ in plant. Phytotoxic limit of DTPA extractable Ni in soil and $\mathrm{Ni}$ content in plant were worked out as $3.24 \mathrm{mg} \mathrm{kg}^{-1}$ and $12.0 \mathrm{mg} \mathrm{kg}^{-1}$, respectively. Maximum value of prediction co-efficient $\left(r^{2}\right)$ indicates that $\mathrm{Ni}$ content in that particular soil or plant sample is a border line, beyond which there is a probability of occurrence of $\mathrm{Ni}$ toxicity. Nickel concentrations more than 10,50 and $1000 \mathrm{mg} \mathrm{kg}^{-1}$ in dry matter of sensitive, moderately tolerant and hyperaccumulator plants have been reported earlier as toxicity limits (Yusuf et al., 2011 and Syam et al., 2016).

The efficacy of soil test method depends on the degree of correlation between available nutrient in soil and its uptake by plant. Ideally such relationship should be linear, which suggests that plant uptake is proportional to the extractable pool of $\mathrm{Ni}$ in soil. This is probably not the case under condition of Ni toxicity as obtained in the present case. In such condition, plant physiological processes including root growth are adversely affected, which leads to non proportional Ni uptake by plant with respect to soil Ni content. This may probably explain the reason of obtaining poor prediction coefficient (although significant).

Several researchers attempted to assess the relationship of phytotoxicity with levels of $\mathrm{Ni}$ in soil and plant (Weng et al., 2003; Kukier and Chaney, 2001, 2004; Seregin and Kozhevnikova, 2006; Fargasova and Molnarova, 2010; Ishtiaq and Mahmood, 2011; Pande et al., 2012). Kukier and Chaney (2001) reported that soil Ni extracted with DTPA and $\mathrm{Sr}\left(\mathrm{NO}_{3}\right)_{2}$ was indicative of the ameliorative effects of amendments and correlated well with $\mathrm{Ni}$ concentration in plant shoots. However, they did not suggest any phytotoxic limits either for soil or plants. Further in 2004, they reported a wide variation (9-122 $\left.\mathrm{mg} \mathrm{kg}^{-1}\right)$ in $\mathrm{Ni}$ concentration in shoots associated with $25 \%$ yield reduction of different plant species. Ishtiaq and Mahmood (2011) demonstrated the adverse effect of Ni toxicity in Igumes, while, Weng et al. (2003) worked out the toxic concentration of free $\mathrm{Ni}^{2+}$ 
in a solution culture using oat as test plant. Fargasova and Molnarova (2010) assessed Ni phytotoxicity in mustard due to use of cutlery-washing waste waters. In none of these studies, phytotoxic limits of $\mathrm{Ni}$ in soil and plant were reported. In the present study, phytotoxic limits of $\mathrm{Ni}$, particularly in plant as worked out is far lower as compared to that reported by Kukier and Chaney (2001). Whereas, there is a close agreement between the phytotoxic limits as worked out in the present study and reported by Pande et al. (2012).

By and large, Ni toxicity reduced the dry matter production of soybean. The phytotoxicity limit of DTPA extractable $\mathrm{Ni}$ was $3.24 \mathrm{mg} \mathrm{kg}^{-1}$, whereas $12.0 \mathrm{mg} \mathrm{Ni} \mathrm{kg}^{-1}$ of soybean shoot could be considered as toxic limit. Such limits will help in assessing the suitability of agricultural land from crop productivity point of view. This aspect is now-a-days becoming more relevant particularly in the face of scarcity of fresh water and consequent increase in use of waste water.

\section{References}

Amari, T., T. Ghnaya, A. Debez, M. Taamali, N.B. Youssef, G. Lucchini, G.A. Sacchib and C. Abdelly: Comparative Ni tolerance and accumulation potentials between Mesembryanthemum crystallinum (halophyte) and Brassica juncea: Metal accumulation, nutrient status and photosynthetic activity. J. Plant Physiol., 171, 1634-1644 (2014).

Anderson, J.G., D.R. Mayer and R.K. Mayer: Heavy metal toxicity levels of nickel, cobalt and chromium in the soil and plants associated with visual symptom and variation in growth of an oat crop. Australian. J. Agril. Res., 24, 557-571 (1973).

Barman, M., S.P. Datta and R.K. Rattan: Identification of the solid phase in relation to the solubility of nickel in alluvial soils. J. Environ. Biol., 35, 901-906 (2014).

Brown, P.H., R.M. Welch and E.E. Carry: Nickel: A micronutrient essential for higher plants. Plant Physiol., 85, 801-803 (1987).

Cate, R.B. and L.A. Nelson: A simple statistical procedure for partitioning soil test correlation data into two classes. Soil. Sci. Soc. Am. Proc., 35, 658-660 (1971).

Cempel, M. and G. Nikel: Nickel: A review of its sources and environmental toxicology. Polish. J. Environ. Stud., 15, 375-382 (2006).

Duda-Chodak, A. and Blaszczyk: The impact of nickel on human health. J. Elementol., 13, 685-696 (2008).

El-Enany, A.E., M.A. Atia, M.H. Abd-Alia and T. Rmadan: Response of bean seedlings to nickel toxicity: Role of calcium. Pak. J. Biol. Sci., 3, 1447-1452 (2000).

Fargasova, A. and M. Molnarova: Assessment of $\mathrm{Cr}$ and Ni phytotoxicity from cutlery-washing waste-waters using biomass and chlorophyll production tests on mustard Sinapis alba L. seedlings. Environ. Sci. Pollut. Res., 17, 187-194 (2010).

Gautam, S. and S.N. Pandey: Growth and biochemical responses of nickel toxicity on leguminous crop (Lens esculantum) grown in alluvial soil. Res. Environ. Life Sci., 1, 25-28 (2008).

Indra, V.S. and Sivaji: Metals and organic components of sewage and sludges. J. Environ. Biol., 27,723-725 (2006).

Ishtiaq, S. and S. Mahmood: Phytotoxicity of nickel and its accumulation in tissues of three Vigna species at their early growth stages. J. Appl. Bot. Food Qual., 84, 223-228 (2011).

Khan, M.R. and M.M. Khan: Effect of varying concentration of nickel and cobalt on the plant growth and yield of chickpea. Australian. J. Basic. Appl. Sci., 4, 1036-1046 (2010).

Krupa, Z., E. Skorzynska, W. Malesymiec and T. Baszynski: Effect of Cd treatment on photosynthetic apparatus and its photochemical activities in greening radish seedling. Photosynthetica, 21,156164 (1987).

Kukier, U. and R.L. Chaney: Amelioration of nickel phytotoxicity in muck and mineral soils. J. Environ. Qual., 30,1949-1960 (2001).

Kukier, U. and R.L. Chaney: In situ remediation of nickel phytotoxicity for different plant species. J. Plant. Nutr., 27, 465-495 (2004).

Lindsay, W.L. and W.A. Norvell: DTPA soil test method for determining available zinc, iron, manganese and copper. Soil. Sci. Soc. Am. J., 42, 421-428 (1978).

Mittler, R.: Oxidative stress, antioxidants and stress tolerance. Trends Plant. Sci., 7, 405-410 (2002).

Nie, J., Y. Pan, J. Shi, Y. Guo, Z. Yan, X. Duan and M. Xu: A comparative study on the uptake and toxicity of nickel added in the form of different salts to maize seedlings. Int. J. Environ. Res. Public Hlth., 12, 15075-15087 (2015).

Page, A.L.: Methods of Soil Analysis. In: Chemical and Microbiological Properties. Vol. 9, Soil Science Society of America, Madison, WI (1982).

Pande, J., P.C. Srivastava and S.K. Singh: Plant availability of nickel as influenced by farmyard manure and its critical toxic limits in french bean. J. PI. Nutr., 35, 384-395 (2012).

Pandolfini, T., R. Babbrielli and C. Comparini: Nickel toxicity and peroxidase activity in seedling of Triticum aestivum $\mathrm{L}$ plant cell. Environment, 15, 719-725(1992).

Sabir, M., A. Ghafoor, M.Z.U. Saifullah, Rehman, H.R. Ahmad and T. Aziz: Growth and metal ionic composition of Zea mays as affected by nickel supplementation in the nutrient solution. Int. J. Agri. Biol., 13,186-190 (2011).

Seregin, I.V. and A.D. Kozhevnikova,: Physiological role of nickel and its toxic effects on higher plants. Russian. J. Plant. Physiol., 53, 257-277 (2006).

Syam, N., T. Wardiyati, M.D. Maghfoer, E. Hndayanto, B. Ibrahim and A. Muchdar: Effect of accumulator plant on growth and nickel accumulation of soybean on metal-contaminated soil. Agri. Agril. Sci. Procedia., 9, 13-16 (2016).

Weng, L., T.M. Lexmond, A. Wolthoorn, J.M. Erwin, W.H. Temminghoff and V. Riemsdijk: Phytotoxicity and bioavailability of nickel: Chemical speciation and bioaccumulation. Env. Toxic. Chem., 22, 2180-2187 (2003).

Yusuf, M., Q. Fariduddin, S. Hayat and A. Ahmad: Nickel: An overview of uptake, essentiality and toxicity in plants. Bull. Environ. Contam. Toxicol., 86, 1-17 (2011). 